PAPER

\title{
What is the ethics of ageing?
}

\author{
Christopher Simon Wareham
}

\section{Correspondence to}

Dr Christopher Simon Wareham, Steve Biko Centre for Bioethics, University of the Witwatersrand, Rm 312, 3rd floor, P.V. Tobias Building, Cnr Carse O'Gowrie and York Road, Parktown, Johannesburg 2193, South Africa;

christopher.wareham@wits. ac.za

Received 12 May 2017 Revised 10 July 2017 Accepted 20 July 2017 Published Online First 3 August 2017
Check for updates

To cite: Wareham CS. $J$ Med Ethics

2018:44:128-132.

\section{ABSTRACT}

Applied ethics is home to numerous productive subfields such as procreative ethics, intergenerational ethics and environmental ethics. By contrast, there is far less ethical work on ageing, and there is no boundary work that attempts to set the scope for 'ageing ethics' or the 'ethics of ageing'. Yet ageing is a fundamental aspect of life; arguably even more fundamental and ubiquitous than procreation. To remedy this situation, I examine conceptions of what the ethics of ageing might mean and argue that these conceptions fail to capture the requirements of the desired subfield. The key reasons for this are, first, that they view ageing as something that happens only when one is old, thereby ignoring the fact that ageing is a process to which we are all subject, and second that the ageing person is treated as an object in ethical discourse rather than as its subject. In response to these shortcomings I put forward a better conception, one which places the ageing person at the centre of ethical analysis, has relevance not just for the elderly and provides a rich yet workable scope. While clarifying and justifying the conceptual boundaries of the subfield, the proposed scope pleasingly broadens the ethics of ageing beyond common negative associations with ageing.

\section{INTRODUCTION}

Applied ethics is home to numerous productive subfields such as procreative ethics, intergenerational ethics and environmental ethics. By contrast, there is far less ethical work on ageing, and there is no boundary work that attempts to set the scope for 'ageing ethics' or the 'ethics of ageing'. Yet ageing is a fundamental aspect of life; arguably even more fundamental and ubiquitous than procreation. This makes it a curious oversight that there is no field designated as the ethics of ageing.

Perhaps this lacuna is a result of the perceived negative associations between ageing, decrepitude and death. Internet searches for ageing and ethics result almost exclusively in articles about what to do with expensive ageing populations, or end-oflife decisions in old age. (It is telling that at one presentation of this material I was slotted into a session on healthcare expenses.)

Whatever the explanation, there is a gap. To fill it, I examine work on ethics and ageing, drawing lessons that are employed to delimit the scope of a coherent subfield of the ethics of ageing. Having done so, I give an indication of the subject matter of ageing ethics before sketching its content, giving examples of significant debates that fall within its scope. While clarifying justified conceptual boundaries of the proposed subfield, the scope presented pleasingly broadens the ethics of ageing beyond negative ideas about ageing.

\section{The need for an ethics of ageing}

Subfields in applied ethics typically fall into four categories: socially important domain of enquiry (eg, procreative ethics, environmental ethics and clinical ethics), methodological approach (eg, principlism and narrative ethics), medical specialty (eg, nursing ethics and psychiatric ethics) or area of technological investigation (eg, genethics and neuroethics). ${ }^{1}$ This article delineates a scope for the ethics of ageing in the first category, to go alongside the ethics of other socially and biologically fundamental areas such as procreation.

What motivates and justifies this type of boundary work on ageing ethics? One motivation is at least partly taxonomic: to fill the above-mentioned gap in the classification of ethical content related to fundamental life processes. A second motivation is that ageing is, as it stands, relatively undertheorised in ethics. Søren Holm points out that:

There is a voluminous bioethical literature on reproduction and the beginning of life, and an almost equally large literature on the very end of life, but the perhaps 20 or 30 years that many of us are hoping to spend between retirement and death are very incompletely theorised in bioethics. ${ }^{2}$

Later I suggest that the scope for ageing ethics encompasses, but is broader than 'the 20 or 30 years... between retirement and death'. However Holm's point concerning the relative lack of attention to this area is important. My hope is that the conception of the ethics of ageing deployed here will provide a clearer focus for work on ethics and ageing.

A third motivation is to dispel an important prejudice about ageing - that subjects related to it are predominantly negative and depressing, with a narrow focus on issues concerning healthcare costs, end-of-life decisions, and increasing decrepitude and dementia. The scope conveyed in this article sets a more positive agenda for ageing ethics.

\section{Flawed boundaries for the ethics of ageing}

What is the proper scope of the ethics of ageing? One way to go about answering this question is to look at answers others have given. Unfortunately, there are few specific attempts to do this. The attempts that exist can be roughly grouped into two categories: the first category attempts to provide 'an ethics of ageing': a normative ethical theory suited to dealing with problems related to the elderly. ${ }^{3}$ The second, larger category attempts to identify a range of problems, while remaining neutral about substantive ethical theories. ${ }^{4-7}$ 


\section{'The' ethics of ageing versus 'An' ethics of ageing}

Frits De Lange's Loving Later Life: An Ethics of Aging is an example of the former type. ${ }^{3}$ De Lange derives a substantive normative theory that he argues is appropriate for dealing with ethical issues related to the elderly. In particular, his theological ethics attempts to describe and justify an ethic of love based on Christian principles. This ethic of love, he argues, is more appropriate for approaching ethical issues relating to the elderly than competitor theories like utilitarianism, deontology and the ethics of care. His aim is an ethics of ageing.

In contrast to De Lange's attempt to develop a substantive normative ethic of ageing, the aim of this article is to sketch a domain or scope of ethical issues to which normative theories such as De Lange's can be applied. Like fields such as procreative ethics, the ethics of ageing should not presuppose a particular normative theory, although it may be the case that, as De Lange claims, certain ethical theories are more appropriate to confront ethical issues in ageing. Instead, the aim is to delineate a range of questions, subject matter and content that can be appropriately dealt with under the banner of the ethics of ageing. Thus, unlike De Lange's work, this article does not propose an ethics of ageing, but instead lays some conceptual groundwork for the ethics of ageing.

\section{The ethics of ageing versus 'ethical issues involving the elderly'}

As mentioned, one way to interrogate the boundaries of the ethics of ageing is to evaluate other attempts to do so. However, although some authors mention specific topics of interest, ${ }^{4}$ to my knowledge there are no attempts to map the conceptual terrain of ageing ethics. An alternative route, then, is to attempt to derive potential conceptions from existing work related to ageing and ethics.

A statement that captures what one might understand by ageing ethics comes from Nancy Jecker's anthology Aging and Ethics. ${ }^{6}$ In the preface, Jecker implies her book concerns 'ethical issues involving the elderly'. Although Jecker does not claim to be defining the scope of ageing ethics, her phrase captures what may be a common intuition about what the subfield might contain. I will suggest that this intuitive understanding does not provide an acceptable scope for the ethics of ageing.

The most promising interpretation of 'ethical issues involving the elderly' as delineating a credible subfield views ageing ethics as ethical issues statistically more likely to arise in relation to the elderly than other groups. ${ }^{7}$ This definition would certainly give the field content. Many ethical issues are more likely to arise in relation to the elderly. For instance, elderly people are more likely to have Alzheimer disease, with all the ethical issues concerning informed consent, personhood and personal identity that this raises.

While this is most defensible delineation of scope derivable from Jecker's quote, it presents two problems shared by any interpretation of ageing ethics as 'ethical issues involving the elderly'. The first is that the word 'involving' decentres the ageing person from the ethical questions being asked. That is, it allows that ageing persons be seen as objects of ethical dilemmas and policy rather than as central-the subjects or agents of ethical discourse. As Holm notes, a great deal of work

has been done on issues raised by specific conditions, for example, Alzheimer and dementia, and on the use of age as criterion for resource allocation in healthcare, but the situation of the old person as such has received little attention. ${ }^{2}$
In many cases the issues that 'involve' the elderly are those of 'dealing with' the problematic elderly, rather than the dilemmas of the ageing persons themselves.

This broad understanding of the ethics of ageing includes consideration of the ageing being as an ethically problematic entity or object for others. This inclusion is undesirable for three reasons. First, this category of issues seems very likely to be adequately covered in other subfields, such as nursing ethics, research ethics and public health ethics. Second, the relative neglect of issues concerning the situation of the ageing person 'as such' should cause us to look for ways to draw attention to this underattended set of issues. Delineating the ethics of ageing to deal exclusively with problems confronting the ageing agent is a useful way of doing so. Third, it makes sense that the persons most directly affected by the ageing process - ageing persons themselves - should be at the centre of the analysis in ageing ethics. Admittedly, none of these reasons is decisive in favour of excluding discussion of the elderly as problematic entities from the scope of ageing ethics. Nonetheless they do create a prima facie case for doing so.

Perhaps even more problematic for the conception of the ageing ethics as 'ethical issues involving the elderly' is the idea that the ethics of ageing should involve only issues concerning the elderly. Rather than corresponding to a particular late life phase, ageing is a process which, on some definitions, occurs throughout life. This has two significant implications for the refined scope. First, it implies that ageing ethics may consider the ethical implications of viewing ageing beings as diachronic or narrative entities. As an example of this, later I mention Kass's view that ageing provides a meaning imbuing structure to a person's whole life. This broader type of consideration cannot properly be said only to involve the elderly.

Second, the fact that ageing occurs throughout life justifies the inclusion of issues related to ageing that arise before one is elderly. For example, problems confronted in so-called mid-life crises are often heavily linked to ageing. The scope of ageing ethics is unjustifiably limited if such concerns are excluded by a narrow focus on the elderly.

\section{The proper scope of the ethics of ageing}

The above considerations provide some criteria that the ethics of ageing should fulfil. First, the ethics of ageing should place the ageing person at the centre. They should be moral agents or subjects rather than problematic objects in the discourse. Second, the ethics of ageing should reflect the idea that ageing occurs, if not throughout the whole course of life, then at least through most of it.

These elements are captured in the following statement:

The ethics of ageing is a field of normative enquiry encompassing ethical issues facing a person in her situation as an ageing person.

Below I make a few clarificatory points before arguing that this definition fulfils the criteria above, sketching some of the questions that fall under the heading and demonstrating how this scope is attractive.

An initial point is that ageing ethics, like other subfields of applied ethics, should contain a normative element. ${ }^{8}$ While descriptive empirical studies and claims are undoubtedly relevant for work in this subfield, ageing ethics should propose or critique moral norms, theories, principles or values.

A further clarification is to elaborate on the term 'in her situation' as ageing person. This distinguishes the ethics of ageing from a field comprising 'ethical issues that confront the ageing 
person'. This is important since, as mentioned, all or most of us are ageing, and so 'issues confronting the ageing person' may logically comprise all ethical issues. While a decision about whether to eat meat is an ethical issue that confronts an ageing person, it is not a question that is raised by her status as ageing person. Thus it is necessary to be clear that the ethics of ageing comprises ethical issues that face a person qua ageing person.

An important point is that this definition explicitly removes issues concerning ageing non-persons, such as most animals and, arguably, the severely mentally impaired, from the centre of analysis. This is not to suggest that non-persons are entirely excluded from the scope of the ethics of ageing. Instead, non-agents fall within the designated scope indirectly, insofar as they relate to ethical issues facing an ageing person. This is not merely person-centric chauvinism. Instead, this limitation stems from the above consideration that an ethics of ageing should have dilemmas facing the ageing subject or moral agent at the centre of the analysis. Only persons can be moral agents in the full sense.

On many definitions of agency, this restriction of the scope of ageing ethics appears controversially to exclude all considerations concerning elderly people with cognitive disorders such as severe dementia. It is important to emphasise that it does not: one of the most significant concerns of ageing persons is the decline and loss of agency. The appropriate response to this prospect thus falls well within the ethics of ageing as defined here.

\section{The subject matter of ageing ethics}

To gain a clearer idea of the types of ethical issues that the ethics of ageing encompasses, it is helpful to consider its distinctive subject matter. By 'distinctive' I am not suggesting that there should be no overlap with other fields. Such cleaving at the joints of enquiry is unlikely to be found in ethics or any other field. Instead, the point is that there should be a core subject matter that properly falls under the category 'ethics of ageing', which can be readily distinguished from debates that more appropriately belong in other subfields of ethics.

The subject matter of ageing ethics can be divided into questions concerning right ageing and good ageing. Ethical dilemmas related to right ageing concern questions about our duties and rights as ageing persons. What ought the ageing person to do in response to ageing-related dilemmas? For instance, the theorist may ask whether it is sometimes morally obligatory for an older person to refuse a treatment so that a younger person may have it. As a further example, ethicists of ageing may address the question of whether forced retirement violates societies' obligations towards ageing persons. ${ }^{9}$

Rather than focusing on rights and duties qua ageing persons, ethical questions related to good ageing focus on well-being. How can we age well or meaningfully? For instance, the theorist may ask which ethical theories allow us to cope best with our status as ageing beings. Which values, goods and harms are most relevant to the ageing person, and which virtues are most relevant to flourishing as one ages? Good ageing also requires a focus on the circumstances and technologies that may impact on the length of life and well-being of the ageing person.

With these clarifications in place, it should be clear that the designated field meets the criteria above: It is neither too narrow nor too broad, encompassing all and only those ethical issues that relate to persons as ageing persons. The ageing person is placed at the centre of moral analysis by definition, since the starting point for analysis is ethical issues confronting a person qua ageing person. Finally the refined scope rightly views ageing as a process, rather than merely as the latest phase in life. According to this scope, the ethics of ageing encompasses ageing-related problems that occur throughout life. I now provide examples of existing debates that fall within this ambit.

\section{Extant work on the ethics of ageing}

With the appropriate scope of the ethics of ageing defined, what is the existing work that falls within this scope? Although the determination of the boundaries of the ethics of ageing has been neglected, questions that fall within its scope have not. For instance, the recently published Palgrave Handbook of the Philosophy of Aging provides examples of the myriad debates that could fall within the corrected scope of the ethics of ageing. ${ }^{10}$ With no attempt to be exhaustive, I sketch some existing and potential areas of debate within the field of the ethics of ageing, many of which appear on the pages of this journal.

\section{Definitional questions}

Above, I have left undetermined the question of how ageing should be defined. This is because it is a substantive issue with which the ethics of ageing should grapple. While some view ageing as a process occurring throughout life, biologists typically regard ageing as 'the time-dependent functional decline that affects most living organisms'. ${ }^{11}$ This characterisation of ageing as intrinsically related to decline and degradation has led some, such as Gunnar De Winter and Arthur Caplan, to suggest that ageing should be regarded biologically as a disease. ${ }^{12}{ }^{13}$ However, biological characterisations of ageing seem to exclude ethical concepts commonly associated with ageing, such as wisdom and experience. Thus, as even some biologists suggest, it is at least partly an ethical question as to whether biological definitions should exhaust the conception of ageing. ${ }^{14}$

A related definitional question concerns how to delineate different phases of ageing. What characterises youth, middle age and elderliness, and are these characteristics static or dynamic as lives become longer?

\section{Intergenerational rights and duties}

An initial controversial area of enquiry in the ethics of ageing, roughly corresponding to subject matter concerning right ageing, concerns intergenerational rights and duties, or the duties of young and old with respect to their status as ageing persons. It is relevant to younger ageing persons why their quality of life should be reduced by taxation to accommodate elderly persons who may not have adequately contributed to a social system. Similarly, it is important to question the justifications for discrimination against the elderly, such as compulsory retirement and 'fair innings' approaches to health allocation decisions. ${ }^{15-17}$ Such discrimination would be entirely unacceptable against other racial, cultural or gender groups.

A debate at the intersection between reproductive ethics and ageing ethics concerns whether it is ethical to have children at a very old age. Given modern reproductive technologies, people are able to have children far later in life. But it is appropriate to ask whether limits are justified. ${ }^{18}$ At what point in the ageing process should one put aside hopes of having children due to potential harms to oneself, the child and society? Is it justified for the state to intervene in an ageing person's decision about her body?

\section{Questions about good, meaningful lives}

What makes lives go better in relation to our status as ageing persons? It is plausible that some ethical theories provide better methods to confront ageing. I have already mentioned De 
Lange's attempt to develop an ethic of ageing for this purpose. As a further example, Rosemary Tong suggests that some virtues may be more appropriate to flourishing at different phases of life. ${ }^{7}$

An important question in this category concerns the value or disvalue of ageing. Is ageing bad for us? Transhumanists, such as Aubrey de Grey and Nicholas Bostrom, see ageing as yet another flawed aspect of human biology - a 'dragon tyrant' that ought to be overcome. ${ }^{19-21}$ However, others such as Michael Hauskeller, Nicolas Agar and Leon Kass to varying degrees regard ageing as an important, value-bestowing aspect of the human condition. $^{22-24}$ Kass in particular implies that ageing is a necessary part of human flourishing since the phases of ageing are important contributors to the meaning and value of life. ${ }^{25} \mathrm{~A}$ similar, though conceptually distinct, possibility is that the trajectory of ageing may influence the goodness of life by resulting in an anticlimactic narrative structure. ${ }^{26}$

The end of the biological ageing process is death, so it is important to consider the value or disvalue of ageing-related death by engaging questions concerning the (dis)value of death. ${ }^{27}$ Deprivation accounts of death's badness suggest that what harms one is the good life of which death deprives one. ${ }^{28} 29$ On such accounts death in decrepit old age may sometimes be good for one, meaning that an important question in ageing ethics concerns conditions under which suicide may be rational for the aged person. ${ }^{30}$

\section{Technology and the future of ageing}

Perhaps the most rapidly expanding area in the ethics of ageing concerns emerging technologies aimed, first, at assisting the elderly and, second, at altering the ageing process. ${ }^{31}$ In the first category, robots are increasingly used in the care of ageing and elderly persons. ${ }^{32}$ This raises significant fears about human robot interactions, the potential for reduced quality of care and the alienation of the ageing person to an inhuman periphery. ${ }^{33}$ Against such concerns, Stahl and Coeckelbergh emphasise a positive role for robot caregivers and suggest that critics ignore novel and positive modes of interaction between robots and ageing persons. ${ }^{34}$ Robots and other emerging technologies pose significant questions for the meaning in the lives of persons qua ageing persons.

The second category involves the ethical implications of technologies directed at altering the ageing process by the modes of slowing, ${ }^{35}$ preventing, ${ }^{36} 37$ reversing ${ }^{38}$ or even escaping ageing. ${ }^{39}$ Which, if any, of these modes can be considered justified given the aforementioned proageing challenges of bioconservatives such as Kass? Which types of technologies are likely to result in increased healthspan along with increased lifespan, and, as an ageing person, do I have a right to such technologies as a corollary to rights to life and health? Are such technologies fair in a world already divided by massive inequalities in healthy lifespan within and between nations, ${ }^{40} 41$ particularly given the burgeoning and perhaps already unsustainable population of the planet? ${ }^{42}$ These significant questions represent part of the content of the ethics of ageing.

\section{CONCLUSION}

The above work represents a fraction of the work that can justifiably said to form part of ageing ethics. While there is overlap with work in other fields such as reproductive ethics, the ethics of emerging technologies and intergenerational ethics, the ethics of ageing, as defined here, has a distinctive core. It designates and gathers together a cluster of ethical issues that confront the ageing person in her situation as ageing person.
The designated scope counters an unfortunate intuition about ageing and ethical issues related thereto - that its subject matter is predominantly negative and depressing, with near exclusive focus on issues of end-of-life decisions, increasing decrepitude and dementia. The subfield outlined here sets a more positive and fruitful agenda for ageing ethics.

Acknowledgements Thanks to delegates at the 12th UNESCO Conference on Bioethics, Medical Ethics and Health Law in Cyprus for helpful comments on an earlier version of this material.

Competing interests None declared.

Provenance and peer review Not commissioned; externally peer reviewed.

(c) Article author(s) (or their employer(s) unless otherwise stated in the text of the article) 2018. All rights reserved. No commercial use is permitted unless otherwise expressly granted.

\section{REFERENCES}

1 Parens E, Johnston J. Does it make sense to speak of neuroethics? EMBO Rep 2007:8:S61-4

2 Holm S. The Implicit Anthropology of Bioethics and the Problem of the Aging Person In: Schermer M, Pinxten W, eds. Ethics, Health Policy and (Anti-) Aging: mixed Blessings. . Dordrecht: springer Netherlands, 2013:59-71.

3 De Lange F. Loving later life: an ethics of aging. Grand Rapids, MI: Eerdmans, 2015. 4 Faul AC, D'Ambrosio JG. Ethics of Aging. The encyclopedia of Adulthood and Aging: John Wiley \& Sons, 2015.

5 Fenech FF. Ethical issues in ageing. Clin Med 2003;3:232-4.

6 Jecker NS, ed. Aging and ethics: philosophical problems in Gerontology. New York: Springer, 1991

7 Tong R. Ethics of Aging. La Follette H, ed. The International Encyclopedia of Ethics. Wiley Online Library, 2013.

8 Kon AA. The role of empirical research in bioethics. Am J Bioeth 2009;9(6-7):59-65

9 Sargeant M. The Default Retirement Age: legitimate aims and Disproportionate Means. Industrial Law Journal 2010;39:244-63.

10 Scarre G, ed. The Palgrave Handbook of the philosophy of aging. New York: Springer, 2016.

11 López-Otín C, Blasco MA, Partridge L, et al. The hallmarks of aging. Cell 2013;153:1194-217.

12 De Winter G, disease AasMed Health Care Philos 2015;18:237-43.

13 Caplan AL. Death as an unnatural process. EMBO Rep 2005;6:S72-S75.

14 Ludwig FC, ed. Life Span Extension: consequences and open questions. New York: Springer, 1991.

15 Williams A. Intergenerational equity: an exploration of the 'fair innings' argument. Health Econ 1997:6:117-32.

16 Walker T, Ageing WT. Ageing, justice and resource allocation. J Med Ethics 2016;42:348-52.

17 Wareham C. Youngest first? why it's wrong to discriminate against the elderly in healthcare. S Afr J Bioeth Law 2015;8:35-9.

18 Gulino M, Pacchiarotti A, Vergallo GM, Montanari Vergallo G, et al. Is age the limit for human-assisted reproduction techniques? 'Yes', said an Italian judge. J Med Ethics 2013;39:250-2.

19 Bostrom N. The fable of the dragon tyrant. J Med Ethics 2005:31:273-7.

20 de Grey $A D$, extension L. Life extension, human rights, and the rational refinement of repugnance. J Med Ethics 2005;31:659-63.

21 Wareham C. The Transhumanist Prospect: Developing Technology to Extend the Human Lifespan. Scarre G, ed. The Palgrave Handbook of the philosophy of aging. New York: springer, 2016:517-38.

22 Hauskeller M. Forever Young? Life Extension and the ageing mind. Ethical Perspect 2011;18:385-405

23 Agar N. Humanity's End: Why We Should Reject Radical Enhancement. London: MIT Press, 2010.

24 Kass LR. L'Chaim And its limits: why not immortality? First Things 2001:113:17-24.

25 Kass LR. Ageless bodies, happy souls: biotechnology and the pursuit of perfection New Atlantis 2003:352:9-28.

26 Velleman JD. Well-being and time. Pacific Philos Q 1991;72:48-77.

27 McMahan J. Death and the value of life. Ethics 1988;99:32-61.

28 Death NT. Nous. . Blackwell Publishing, 1970:vol 4. 73-80.

29 Wareham C. Deprivation and the See-saw of death. South African J Philos 2009.

30 Davis DS. Alzheimer disease and pre-emptive suicide. J Med Ethics 2014;40.

31 Read CY, Green RC, Smyer MA, et al. Aging, biotechnology, and the future: JHU Press, 2008.

32 Preuß D, Legal F. Living with the animals: animal or robotic companions for the elderly in smart homes? J Med Ethics 2016.

33 Frennert S, Östlund B. Review: seven matters of concern of Social Robots and older people. Int J Soc Robot 2014:6:299-310.

34 Stahl BC, Coeckelbergh M. Ethics of healthcare robotics: towards responsible research and innovation. Rob Auton Syst 2016;86:152-61. 
35 Gems D. Is more life always better? the new biology of aging and the meaning of life. Hastings Cent Rep 2003;33:31-9.

36 Moen OM. The case for cryonics. J Med Ethics 2015;41:677-81.

37 Shaw D. Cryoethics: seeking life after death. Bioethics 2009:23:515-21.

38 Jaskelioff M, Muller FL, Paik JH, et al. Telomerase reactivation reverses tissue degeneration in aged telomerase-deficient mice. Nature 2011; 469:102-6.
39 de Grey ADNJ. Escape velocity: why the Prospect of Extreme Human Life Extension matters now. PLoS Biol 2004; 2: e187-6.

40 Wareham CS. Substantial Life Extension and the Fair distribution of Healthspans. J Med Philos 2016;41:521-39.

41 Pijnenburg MA, Leget C. Who wants to live forever? three arguments against extending the human lifespan. J Med Ethics 2007;33:585-7.

42 Wareham C. Slowed ageing, welfare, and population problems. Theor Med Bioeth 2015;36:321-40 